\title{
Single and combined effects of CSN1S1 and CSN2-casein genes on Awassi sheep milk quantity and quality
}

\author{
Ahmad H. Al-Amareen ${ }^{1}$ and Khaleel I. Jawasreh² ${ }^{(D)}$ \\ 1. Livestock Directorate, National Agriculture Research Center, Albaqa'a 19381, Jordan; 2. Department of Animal \\ Production, Jordan University of Science and Technology, Irbid 22110, Jordan. \\ Corresponding author: Ahmad H. Al-Amareen, e-mail: ahmad_alathamna@yahoo.com \\ Co-author: KIJ: kijawasreh@just.edu.jo \\ Received: 25-10-2021, Accepted: 18-01-2022, Published online: 25-02-2022
}

doi: www.doi.org/10.14202/vetworld.2022.435-441 How to cite this article: Al-Amareen AH, Jawasreh KI (2022) Single and combined effects of CSN1S1 and CSN2-casein genes on Awassi sheep milk quantity and quality, Veterinary World, 15(2): 435-441.

\begin{abstract}
Background and Aim: Milk produced from Awassi sheep is of high nutritive value; its production is relatively low in Awassi sheep, so the genetic improvement programs targeted milk production and its components are of high importance, especially when using genes that have an important signal to milk traits. This study was aimed at assessing the influence of alpha S1 (CSN1S1) and beta-casein (CSN2) genes genotypes interaction on Awassi ewes milk productivity.
\end{abstract}

Materials and Methods: A total number of 391 milk yield and its composition records (taken through five consecutive years, 2007-2011) of 167 ewes were utilized for this study. DNA samples were extracted from the ewe's blood samples, then the polymerase chain reaction products of alpha $\mathrm{S} 1$ (CSN1S1) and beta-casein (CSN2) genes were sequenced. The obtained sequences were analyzed; thereafter, the detected variants were tested for their possible association with milk traits.

Results: The CSN1S1 and CSN2 variants allelic frequencies were 0.85 and 0.15 , and 0.95 and 0.05 , respectively. Lactose and solid not fat (SNF) \% were associated with TC CSN1S1 genotypes. No association was found among CSN1S1 polymorphic genotypes with milk production, lactose, and SNF \% were associated with TC CSN1S1 genotypes. Ewes of CSN2 AC genotype showed higher milk production traits, while no association was found between milk composition traits and CNS2 genotypes. Nevertheless, CSN1S1 *CSN2 interaction showed the highest SNF, fat percentages, and milk production.

Conclusion: The substantial interaction effects between CSN1S1 $\times$ CSN2 genes were significantly affected the amount of milk, fat, and SNF\% produced. The detected variants should be included in the breeding programs of Awassi sheep that are designed for improving their milk quantity and quality.

Keywords: Awassi sheep, fat, gene, interaction, milk yield, protein.

\section{Introduction}

The potential use and incorporation of the genes that encoded milk proteins in breeding programs are of high importance; their pivotal role in enhancing the productivity and the manufacturing properties of sheep's milk is highly recommended [1-3]. The mammary glands found in the ewe's udder secret milk proteins by its epithelial cells [4]. The most abundant proteins found in sheep's milk is the caseins $(80 \%)$ in addition to whey proteins. Four groups of caseins were found, namely, alpha-S1-(CSN1S1), alpha-S2-(CSN1S2), beta-(CSN2), and kappa-(CSN3) caseins $[4,5]$. The genetic code of the casein proteins $(250 \mathrm{~kb})$ is located on chromosome number 6 of the ovine genome [6]. Moioli et al. [7] and Gras et al. [8] reported missense variants that cause changes in the protein's amino acid which, directly altered the protein's structure, some missense mutations, or variants

Copyright: Al-Amareen and Jawasreh. Open Access. This article is distributed under the terms of the Creative Commons Attribution 4.0 International License (http://creativecommons.org/licenses/ by/4.0/), which permits unrestricted use, distribution, and reproduction in any medium, provided you give appropriate credit to the original author(s) and the source, provide a link to the Creative Commons license, and indicate if changes were made. The Creative Commons Public Domain Dedication waiver (http:// creativecommons.org/publicdomain/zero/1.0/) applies to the data made available in this article, unless otherwise stated. have been observed to affect milk quality and quantity. Furthermore, the quality and the yield of cheese were improved following including casein variants into the selection programs of dairy sheep.

Due to its extraordinary micelle structure, Alpha S1-casein coded by the CSN1S1 gene plays a pivotal role in yielding high amounts of cheese $[5,9]$. Chessa et al. [10] indicated CSN1S1 protein to account for $47.21 \%$ of ovine whole milk proteins. At the DNA level, one missense variant (rs420959261) was detected within the CSN1S1 gene in exon number 17. Ceriotti et al. [11] reported a mutation in this single nucleotide polymorphism (SNP) that causes substitution in $\mathrm{p}$. Thr186Ile which intern change the CSN1S1*T protein variants from $\mathrm{T}$ to $\mathrm{C}$. Ruminants milk components such as milk fat and protein contents in addition to cheese yield were observed to be highly associated with different CSN1S1 variants as stated by Giambra et al. [12] and Moioli et al. [7]. Beta-casein constitutes about $50 \%$ of the total proteins found in milk, which, encoded by CSN2 gene that has a pivotal role in the manufacturing properties of milk such as the formation process of micelles and its stabilization [5]. Moreover, CSN2 is a member of casein cluster of 13 known protein variants; it is the most polymorphic milk protein gene. Due to its 
unique specifications, CSN2 may act as a powerful biological marker for improving milk traits. The complete nucleotide sequence of CSN2 was described by Provot et al. [13]. As appeared in the NCBI, the CSN2 gene contains 9 exons; the largest exons are 7 and 9 and 492 and $323 \mathrm{bp}$ in size, respectively. CSN2 gene contains an SNP (rs430298704) which, substitute p. Met183Val that alter A and $\mathrm{G}$ protein alleles in addition to another one called rs416941267) [14]. Chessa et al. [10] reported a missense mutation (rs416941267) in the CSN2 that changed $\mathrm{C}$ to $\mathrm{A}$ protein alleles inCSN2. The molecular characterization and the association between CSN2 polymorphisms with milk performance were studied in sheep $[12,15,16]$.

This is the first study designed to screen the commercial Awassi sheep CSN1S1 and CSN2 genes loci and investigate their single and combined effects on CSN2 genes and their association with milk production and composition.

\section{Materials and Methods}

Ethical approval

The procedures used in this project were approved (approval No. 16/3/3/578) by the Animal Care and Use Committee of Jordan University of Science and Technology.

\section{Study period and location}

The study used the records of 2007-2011. The study was conducted in the commercial sheep flocks distributed in the southern, middle and Northern regions of Jordan.

\section{Animal and performance data}

The full details of the fieldwork description, milk quantities and qualities, samples collection, analysis, and the studied flocks' management were described in detail by Jawasreh et al. [17]. Out of 928 ewes available for this project, 391 full lactation records on 167 ewes were selected according to their measurement accuracy and the availability of pedigree information. All the inclusion and exclusion criteria are described in the study of Jawaresh et al. [17].

\section{DNA isolation and DNA segment amplification}

Blood samples $(5 \mathrm{~mL})$ from each of 167 Awassi ewes were drained from the jugular vein using vacuum tubes treated with $0.25 \%$ Ethylene Diamine Tetraacetic Acid (BD Vacutainer Systems, Plymouth, UK) and stored at $-20^{\circ} \mathrm{C}$ until DNA isolation that was conducted 2 weeks following collection. DNA was isolated from the whole blood samples using Wizard Genomic DNA Extraction Kit (OMGA-Bio-Tek, Inc., Madison., WI, USA), according to the manufacturer's instructions, and then stored at $-20^{\circ} \mathrm{C}$. The quality of the obtained DNAs was tested using agarose gel electrophoresis (Cleaver Scientific Ltd, Belgium). The studied genetic regions were amplified after obtaining the specific primers that target exon 7 ofCSN2 and exon 17 of the CSN1S1 genes (Table-1) [11,18]. Polymerase chain reaction (PCR) amplifications mixture contained nuclease-free water $(10 \mu \mathrm{L})$, template genomic DNA $(100 \mathrm{ng} / \mu \mathrm{L})(2 \mu \mathrm{L})$, two $\mu \mathrm{L}$ from each of the prepared primers, and Taq DNA polymerase (4 $\mu \mathrm{L}[5 \mathrm{U} / \mu \mathrm{L}])$. Primer sequences and annealing temperature are shown in Table-1. The PCR reaction mixtures were performed using a thermal cycle parameter at $95^{\circ} \mathrm{C}$ for $5 \mathrm{~min}$ as initial denaturation step followed by 33 cycles at $95^{\circ} \mathrm{C}$ for $30 \mathrm{~s}, 40 \mathrm{~s}$ annealing and extension each at $72^{\circ} \mathrm{C}$, and a final extension step at $72^{\circ} \mathrm{C}$ for $7 \mathrm{~min}$ (Table-1). The PCR products were visualized on a $2 \%$ agarose gel stained with bromide (Bio Basic Inc., Canada) and visualized under ultraviolet light.

\section{Sequencing analysis}

The primers (Table-1) used for amplification were also included for obtaining the nucleotide sequences. The PCR products of the different genotype patterns of the CSN1S1 and CSN2 genes were purified and sequenced by Macrogen Incorporation (Seoul, South Korea) to identify the SNPs found in these different genotype patterns. The nucleotide sequences and alignments were analyzed by BioEdit software version 5.0.6. [19].

\section{Statistical analysis}

The genotype and allelic frequencies of the CSN2 and CSN1S1 loci, and their probable deviations from Hardy-Weinberg equilibrium were evaluated by PopGene32 package version 1.31 programs [20]. The leastsquares method applied in the mixed model procedure of SAS/STAT $®$ software (SAS Institute Inc., Cary, NC, USA, v9.1) was used to investigate the single and combined impact of CSN2 and CSN1S1 genes on the studied traits using two statistical models as described below:

The first model was used to estimate the impact of the detected mutations on milk production traits analysis was:

$$
\mathrm{Yijk} 1 \mathrm{mno}=\mu+C S N 1 S 1 \mathrm{i}+C S N 2 \mathrm{j}+\mathrm{Pk}+\mathrm{D}(\mathrm{S})
$$

$\mathrm{I}+\mathrm{SYm}+\beta \mathrm{nDWn}+(C S N 1 S 1 \times C S N 2) \mathrm{ij}+$ eijklmno

Where:

- Yijklmno=The value of each studied trait

- $\mu=$ Overall mean of the total milk yield (TMY) or test day milk (TDM) yield

- $\quad$ CSN1S1 $\mathrm{i}=$ The effect of the $\mathrm{i}^{\text {th }}$ genotype at CSN1S1 locus ( $\mathrm{i}=\mathrm{TT}$ and $\mathrm{TC})$

- $\quad C S N 2 \mathrm{j}=$ The effect of the $\mathrm{j}^{\text {th }}$ genotype at CSN2 locus $(\mathrm{j}=\mathrm{CC}$ and $\mathrm{CA})$

- $\quad \mathrm{Pk}_{\mathrm{k}}=$ The effect of the $\mathrm{k}^{\text {th }}$ parity or number of lambing $(\mathrm{K}=1,2,3,4,5$ and 6$)$

- $\mathrm{D}(\mathrm{S}) \mathrm{l}=$ The effect of $\mathrm{I}^{\text {th }}$ dams within sires $(\mathrm{l}=1$, 2-30); (Random effect)

- $\quad \mathrm{SYm}=$ Fixed effect of the $\mathrm{m}^{\text {th }}$ year-season of lambing $(\mathrm{m}=1-5)$

- $\quad \beta n=$ Regression coefficient dam weight at lambing

- $\mathrm{DWn}=$ Dam weight at lambing as a covariate

- $\quad(C S N 1 S 1 \times C S N 2)$ ij=Interaction between CSN1S1 genotypes and CSN2 genotypes (ij=TTCC, TTCA, TCCC, and TCCA);

- eijklmno=random errors with the assumption of $\mathrm{N}\left(0, \sigma^{2}\right)$. 
Table-1: The primers information used in this study.

\begin{tabular}{|c|c|c|c|c|}
\hline Gene & Primers $\left(5^{\prime} \rightarrow 3^{\prime}\right)$ & $\operatorname{TM}\left({ }^{\circ} \mathrm{C}\right)$ & $\begin{array}{l}\text { Polymerase chain } \\
\text { reaction product (bp) }\end{array}$ & Reference \\
\hline AlphaS1-casein (CSN1S1) & $\begin{array}{l}\text { F: CACTGTTGCTITTCAATGGC } \\
\text { R: AAGGCAACAATATGCAGTCATTT }\end{array}$ & 56 & 223 & [11] \\
\hline Bata-casein (CSN2) & $\begin{array}{l}\text { F: CTTCTTTCCAGGATGAACTCC } \\
\text { R: GACTTACAAGAATAGGGAAGG }\end{array}$ & 52 & 510 & {$[18]$} \\
\hline
\end{tabular}

TM=Annealing temperature

The second model used to estimate the effects of the mutations on milk composition traits analysis was:

Yijklmno $=\mu+C S N 1 S 1 \mathrm{i}+C S N 2 \mathrm{j}+\mathrm{Pk}+\mathrm{S} 1+\mathrm{TOBm}$

$+\mathrm{AGEn}+\beta \mathrm{oDWo}+\beta \mathrm{pTDMp}+(C S N 1 S 1 \times C S N 2)$

ij+eijklmnopq

Where:

- Yijklnmopq=The studied traits

- $\mu=$ Overall mean of Fat \%; protein \%, solid not fat (SNF) $\%$, Total solids, lactose $\%$, and density $\left(\mathrm{g} / \mathrm{cm}^{2}\right)$

- CSN1Sli=Fixed effect of the $\mathrm{i}^{\text {th }}$ genotype at CSN1S1 locus ( $\mathrm{i}=\mathrm{TT}$ and TC)

- $\quad C S N 2 \mathrm{j}=$ Fixed effect of the $\mathrm{j}^{\text {th }}$ genotype at CSN2 locus $(\mathrm{j}=\mathrm{CC}$ and $\mathrm{CA})$

- $\mathrm{Pk}=$ Fixed effect of the $\mathrm{k}^{\text {th }}$ parity or number of lambing ( $\mathrm{k}=1,2,3,4,5$ and 6$)$

- $\quad \mathrm{Sl}=$ Random effect of $\mathrm{l}^{\text {th }}$ sires $(1=1,2 \ldots, 31)$

- TOBm=Fixed effect of the $\mathrm{m}^{\text {th }}$ type of birth $(\mathrm{m}=\mathrm{s}-$ ingle and twin)

- AGEn=Fixed effect of the $\mathrm{n}^{\text {th }}$ age of dam $(\mathrm{n}=2-7)$

- $\beta o=$ Linear regression coefficient dam weight at lambing

- $\mathrm{DWo}=$ Dam weight at lambing as a covariate

- $\beta p=$ Linear regression coefficient TDM

- $\mathrm{TDMp}=\mathrm{TDM}$ covariant

- $(C S N 1 S 1 \times C S N 2) \mathrm{ij}=$ Interaction between CSN1S1 genotypes and CSN2 genotypes $(\mathrm{ij}=$ TTCC, TTCA, TCCC, and TCCA)

- eijklmnopq=Random errors with the assumption of $\mathrm{N}\left(0, \sigma^{2}\right)$.

All statistical comparisons between genotypes and traits were considered to be significant when $\mathrm{p}<0.05$.

\section{Results}

\section{Descriptive statistics}

In the obtained data that measured on the commercial flocks, the necessary test statistics were generated (Table-2), including; the means and their standard errors, coefficients of variation (CV), which are presented in Table-2. The standard errors of the means of milk production and composition were very low, while the other statistics such as CV indicated the high diversity within the studied flocks indicting high $\mathrm{CV}$ for fat percentage and milk production but relatively average coefficient of variation for lactose and protein percentages, that promoting and escalating the selection gain in the two studied traits recorded in these flocks.
Table-2: Milk production and composition simple statistics calculations in the studied population.

\begin{tabular}{|c|c|c|c|c|}
\hline Traits & No. of records & Mean & SE & CV $(\%)$ \\
\hline \multicolumn{5}{|c|}{ Milk production traits $(\mathrm{kg})$} \\
\hline TMY & 576 & 105.9 & 2.09 & 47.3 \\
\hline TDM & 576 & 0.933 & 0.02 & 40.4 \\
\hline \multicolumn{5}{|c|}{ Milk composition trait } \\
\hline Fat\% & 917 & 5.80 & 0.05 & 25.7 \\
\hline SNF\% & 986 & 9.74 & 0.03 & 8.30 \\
\hline Protein\% & 986 & 3.90 & 0.02 & 13.0 \\
\hline Lactose \% & 986 & 5.10 & 0.02 & 13.9 \\
\hline Density $\mathrm{g} / \mathrm{cm}^{2}$ & 986 & 34.3 & 0.10 & 9.4 \\
\hline
\end{tabular}

TMY =Total milk yield, CV=Coefficient of variation (\%), TDM=Test-day milk, SNF=Soluble-not-fat, $\mathrm{SE}=$ Standard error

\section{Sequence analysis of the CSN1S1 and CSN2 genes}

The regions spanning from exon number 17 to the 3' flanking region of the CSN1S1 ovine gene and that spanning from exon number 7 to the 3' flanking region of the CSN2 gene were amplified. The PCR amplified product of the CSN1S1 gene had a size of 223bp, while that of CSN2 gene was 510bp (Figures-1 and 2). BioEdit software was performed for the alignment process and analysis of the sequences generated from the PCR products (Figures-1 and 2). The sequence analysis of exon 17 in CSN1S1 gene revealed a missense mutation $(\mathrm{C}>\mathrm{T})$ at $14079 \mathrm{bp}$ (relative to the gene size) that caused a change in the codons ACT/ATT and new amino acid formation (Threonine/Isoleucine). In exon 7 of the CSN2 gene, a missense mutation $(\mathrm{C}>\mathrm{A})$ at $6083 \mathrm{bp}$ caused codon change (CTT/ATT) and new amino acid formation (Leucine/Isoleucine) was appeared (Figures-1 and 2). Three genotypes in CSN1S1 locus were observed (TT, $\mathrm{TC}$, and $\mathrm{CC}$ ) while only two Ac and $\mathrm{CC}$ were detected in CSN2 genetic locus.

\section{Allelic and genotypic frequencies of CSN1S1 and CSN2 mutations}

The CSN1S1 and CSN2 genes and allele frequencies are summarized in Table- 3 . The frequencies of $\mathrm{T}$ and $\mathrm{C}$ alleles at the locus studied in CSN1S1 gene were 0.85 and 0.15 , respectively, being the TT genotype as the most common genotype $(0.72)$, followed by TC (0.27). In contrast, $\mathrm{CC}$ genotype was rarely found in the Awassi sheep (0.01) genome. For the CSN2 gene, the frequency of $\mathrm{CC}$ genotype was of high prevalence (0.89), while AC was 0.11 and AA was absent in the studied Awassi sheep population. Overall, A allele was of lower frequency than $\mathrm{C}$ allele $(0.05$ and 0.95 , respectively). According to Chi-square test results that investigated the equilibrium of Hardy-Weinberg 
indicated all genotypic frequencies in the studied population to be in equilibrium $(\mathrm{p}<0.05)$, suggesting that the CSN1S1 and CSN2 gene in the investigated population were not influenced by the selection of other evolutionary forces (Table-3).

\section{The impact of CSN1S1 and CSN2 genotypes and some fixed on Awassi milk traits}

The environmental factors that may affect the composition and the amount of milk produced are presented (Table-4). A highly significant impact $(\mathrm{p}<0.05)$ of parity, year-season of lambing and Dam within sire, on milk composition and production traits were observed. However, TDM and TMY were not affected by the CSN1S1 gene genotypes ( $>0.05$ ), while CSN2 gene significantly affected TDM and TMY $(p<0.05)$. A significant interaction effect was observed between CSN1S1 and CSN2 loci on TDM and TMY ( $<0.04$ and 0.05$)$.

Furthermore, SNF\% and lactose\% were significantly $(\mathrm{p}<0.05)$ affected by CSN1S1 mutation

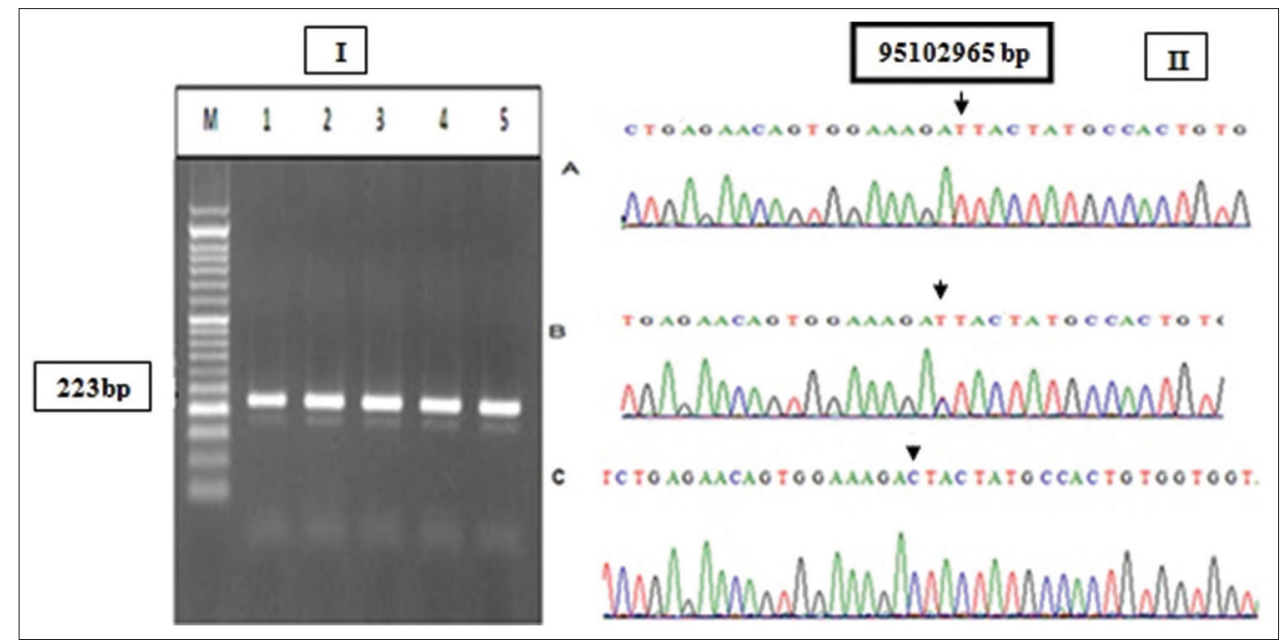

Figure-1: (I) Agarose gel electrophoresis stained with ethidium bromide showing the polymerase chain reaction (PCR) product of as1-Casein gene (CSN1S1). M: 50-bp ladder. Lanes 1-5: 223-bp. (II) The sequence of CSN1S1 PCR product, (A) TT genotype, (B) TC genotype, and (C) CC genotype at position $85102965 \mathrm{bp}$ of the gene located at the $6^{\text {th }}$ ovine chromosome.

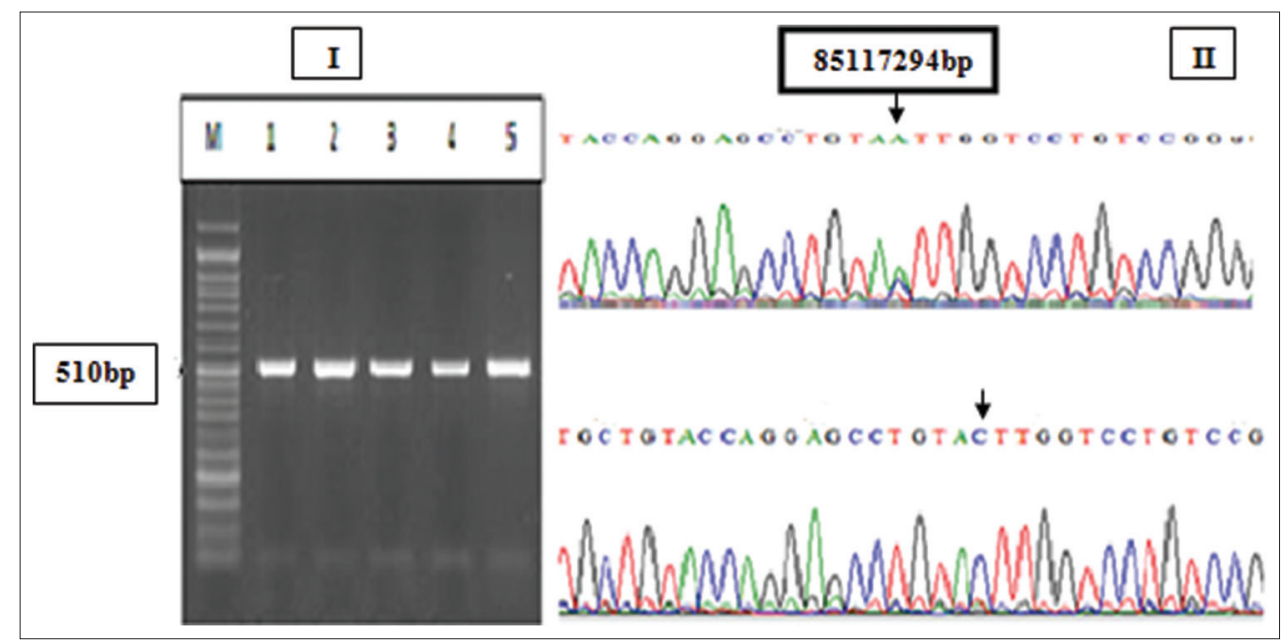

Figure-2: (I) Agarose gel electrophoresis stained with ethidium bromide showing the polymerase chain reaction (PCR) product of beta-casein (CSN2) gene. M: 50-bp ladder. Lanes 1-5: 510-bp. (II) The sequence of the PCR product results of the CSN2 gene a mutation variant located at $8511729 \mathrm{bp}$ on the $6^{\text {th }}$ ovine chromosome, (A) AC genotype and (B) The CC genotype.

Table-3: CSN1S1 and CSN2 genotypic and allelic frequencies in Awassi sheep.

\begin{tabular}{|c|c|c|c|c|c|c|c|}
\hline Gene $^{1}$ & Genotype & Observed number & Expected number & Genotype frequency & Allele & Allele frequency & $\chi^{2}$ \\
\hline CSN1S1 & $\pi$ & 114 & 115.3 & 0.72 & $\mathrm{~T}$ & 0.85 & $0.74^{\mathrm{ns}}$ \\
\hline \multirow{2}{*}{$(n=158)$} & TC & 42 & 39.3 & 0.27 & $\mathrm{C}$ & 0.15 & \\
\hline & $\mathrm{CC}$ & 2 & 3.34 & 0.01 & & & \\
\hline CSN2 & $\mathrm{CC}$ & 143 & 143.5 & 0.89 & $\mathrm{C}$ & 0.95 & $0.50^{\mathrm{ns}}$ \\
\hline$(n=160)$ & CA & 17 & 16.1 & 0.11 & A & 0.05 & \\
\hline
\end{tabular}

${ }^{1}$ CSN1S1 =AlphaS1 casein, CSN2=Beta-casein, $n=$ Number of animals, ns= Non-significant $(p>0.05)$ 
Table-4: $\mathrm{P}$ values for the studied milk traits.

\begin{tabular}{|c|c|c|c|c|c|c|c|}
\hline \multirow[t]{2}{*}{ Trait factors } & \multicolumn{2}{|c|}{ Milk Production' ${ }^{1}$} & \multicolumn{5}{|c|}{ Milk Components } \\
\hline & TMY (kg) & TDM (kg) & Fat $\%$ & SNF\% & Protein \% & Lactose $\%$ & Density, $\mathrm{g} / \mathrm{cm}^{2}$ \\
\hline CSN1S1 & 0.945 & 0.368 & 0.576 & 0.040 & 0.960 & 0.05 & 0.115 \\
\hline CSN2 & 0.037 & 0.001 & 0.615 & 0.489 & 0.474 & 0.940 & 0.572 \\
\hline Dam (Sire) & $<0.0001$ & $<0.0001$ & & & & & \\
\hline Year & $<0.0001$ & 0.002 & & & & & \\
\hline Parity & 0.004 & 0.005 & 0.569 & 0.039 & 0.473 & 0.063 & 0.069 \\
\hline Sire & & & 0.004 & $<0.0001$ & 0.0002 & 0.009 & 0.001 \\
\hline TOB & & & 0.055 & 0.054 & 0.070 & 0.560 & 0.063 \\
\hline Age of dam & & & 0.067 & 0.042 & 0.022 & 0.045 & 0.069 \\
\hline CSN1S1 1 CSN2 & 0.05 & 0.042 & 0.025 & 0.012 & 0.309 & 0.161 & 0.162 \\
\hline Dam weight at lambing & 0.532 & 0.020 & 0.031 & 0.005 & 0.207 & 0.045 & 0.120 \\
\hline Test day milk & & & 0.0003 & $<0.0001$ & $<0.0001$ & 0.132 & $<0.0001$ \\
\hline
\end{tabular}

${ }^{1}$ Mixed-model results of the included fixed effects, TDM=Test-day milk, SNF=Solids-non-fat, TMY=Total milk yield, CSN1S1=Alpha S1-casein, CSN2=Beta-casein

locus. The $C S N 2$ gene variants were non-significantly affected any of milk composition investigated traits (Table-4). Milk composition was affected by sire $(\mathrm{p}<0.05)$, and parity was significantly affected SNF percentage $(p<0.05)$. Type of birth has no significant effect on composition milk traits ( $>>0.05)$, while age of ewe significantly affected SNF\%, protein $\%$, and lactose $\%(p<0.05)$. A significant interaction effect was observed on fat $\%$ and $\mathrm{SNF} \%$ at $\mathrm{p}<0.025$ and 0.012 , respectively.

\section{Single and combined effects of CSN1S1 and CSN2}

The single and combined impacts of CSNISland CSN2 genotypes on milk productivity are shown in Table-5. The single gene effect of CSN1S1 indicated no association ( $>0.05)$ with milk amount produced from Awassi ewes. For CSN2 gene, the highest milk produced was obtained from those ewes of CA (Table-5) genotype.

The combined effects of the two genes $(C S N 1 S 1 \times C S N 2)$ are presented in Table-5. The outcomes from the combined effect of CSN1S1 $\times C S N 2$ pointed out that the individuals of TT $\times$ CA genotype produced significantly the highest amount of milk (TDM and TDY) produced compared to the other genotypes.

\section{Single and combined effects of CSN1S1 and CSN2 genotypes on milk composition traits and their interactions}

The association of different CSN1S1 and CSN2 genotypes and their interactions with milk composition are shown in Table-6. The lactose and SNF percentage in Awassi milk was affected by CSN1S1 gene where TC genotype individuals produced the highest percentage of lactose $\%$ and SNF\% compared to the TT genotypes $(\mathrm{p}<0.05)$. The CSN2 gene showed no significant $(\mathrm{p}>0.05)$ association with all milk composition traits. Compared to their other respective genotypes; TT $\times \mathrm{CC}$ and $\mathrm{TC} \times \mathrm{CA}$ genotype $(C S N 1 S 1 \times C S N 2)$ showed the highest fat $\%$, while $\mathrm{TC} \times \mathrm{AG}$ genotype recorded the highest SNF\% (Table-6).

\section{Discussion}

This study reported single and combined effect of CSN1S1 and CSN2 genotypes and their possible
Table-5: The single and combined effects of CSN1S1 and CSN2 genotypes on test day (TDM) and TMY production in Awassi sheep.

\begin{tabular}{|c|c|c|c|c|}
\hline \multirow[t]{2}{*}{ Gene } & \multirow[t]{2}{*}{ Genotype } & \multirow[t]{2}{*}{$n$} & \multicolumn{2}{|c|}{$\begin{array}{l}\text { Least square means } \\
( \pm S . E)\end{array}$} \\
\hline & & & TMY (kg) & TDM (kg) \\
\hline \multirow[t]{2}{*}{ CSN1S1 } & $T \mathrm{~T}$ & 377 & $137.1 \pm 18.6$ & $1.191 \pm 0.11$ \\
\hline & TC & 118 & $135.2 \pm 16.6$ & $1.030 \pm 0.12$ \\
\hline \multirow[t]{2}{*}{ CSN2 } & $\mathrm{CC}$ & 455 & $107.2 \pm 12.0^{b}$ & $0.796 \pm 0.08^{b}$ \\
\hline & CA & 50 & $165.2 \pm 22.0^{a}$ & $1.425 \pm 0.14^{a}$ \\
\hline \multirow[t]{4}{*}{ CSN1S1×CSN2 } & ТТСС & 360 & $95.0 \pm 7.71^{c}$ & $0.794 \pm 0.05^{b}$ \\
\hline & ТTCA & 17 & $175.6 \pm 33.0^{a}$ & $1.589 \pm 0.21^{a}$ \\
\hline & TCCC & 85 & $119.5 \pm 23.0^{\mathrm{bc}}$ & $0.798 \pm 0.15^{b}$ \\
\hline & TCCA & 33 & $154.7 \pm 33.2^{\mathrm{ab}}$ & $1.262 \pm 0.22^{\mathrm{a}}$ \\
\hline
\end{tabular}

TMY=Total milk yield, TDM=Test-day milk. a,b,cMean within the same row with superscripts differ according to the indicated level of significance $(p<0.05)$.

association with milk composition and Awassi sheep production. Regardless of the essential function of casein genes variants on the economic milk traits, there is a shortage in studies concerning the ovine milk genetic polymorphisms compared with other published work in cattle and goat. Different genotypes and allelic frequencies were observed in CSN1S1 and CSN2 genes of the Jordanian commercial Awassi sheep (Table-3).

The $\mathrm{T}$ allele was observed of high frequency (0.85) compared to the C allele (0.15) of CSN1S1 locus in Awassi sheep. Similarly, it was found to be at 0.71 in Switzerland Lacaune sheep [12], 0.85 in Barki, 0.68 Rahmani, and 0.90 Ossimi sheep [21], 0.53 in German East Friesian Dairy [22], 0.65 in Gentile di Puglia and Massese, 0.73 in Comisana, 0.81 in Sopravissana, and 0.89 in Sarda breed [16]. However, the polymorphisms detected in milk traits of Awassi were not associated with CSN1S1 gene (Table-5). Our results were comparable with the findings published by Giambra et al. $[12,22]$ in East Friesian and Lacaune sheep, as they reported milk yield to be not affected by CSN1S1 genotypes. Milk production of the Spanish Assaf was also not affected by CSN1S1 genotypes [23]. Protein, fat content, and milk density were non significantly affected by CSN1S1 variants, whereas lactose and 
Table-6: Single and combined effect of CSN1S1 and CSN2 genotypes on milk composition traits in Awassi sheep.

\begin{tabular}{|c|c|c|c|c|c|c|c|}
\hline \multirow[t]{2}{*}{ Gene } & \multirow[t]{2}{*}{ Genotype } & \multirow[t]{2}{*}{$\mathbf{n}$} & \multicolumn{5}{|c|}{ Traits least square means ( \pm S.E) } \\
\hline & & & Fat $\%$ & SNF \% & Protein \% & Lactose \% & Density, $\mathbf{g} \backslash \mathrm{cm}^{2}$ \\
\hline \multirow[t]{2}{*}{ CSN1S1 } & $\pi$ & 685 & $5.53 \pm 0.22$ & $9.53 \pm 0.12^{b}$ & $3.90 \pm 0.07$ & $4.98 \pm 0.10^{\mathrm{b}}$ & $33.4 \pm 0.46$ \\
\hline & $\mathrm{TC}$ & 223 & $5.40 \pm 0.19$ & $9.80 \pm 0.10^{\mathrm{a}}$ & $3.90 \pm 0.06$ & $5.20 \pm 0.09^{a}$ & $34.2 \pm 0.40$ \\
\hline \multirow[t]{2}{*}{ CSN2 } & $\mathrm{CC}$ & 814 & $5.40 \pm 0.16$ & $9.62 \pm 0.08$ & $3.75 \pm 0.05$ & $5.09 \pm 0.07$ & $33.9 \pm 0.32$ \\
\hline & CA & 94 & $5.53 \pm 0.25$ & $9.71 \pm 0.13$ & $3.82 \pm 0.08$ & $5.08 \pm 0.12$ & $33.6 \pm 0.53$ \\
\hline \multirow[t]{4}{*}{ CSN $1 S 1 \times C S N 2$} & ТTCC & 654 & $5.75 \pm 0.15^{\mathrm{a}}$ & $9.65 \pm 0.07^{b}$ & $3.79 \pm 0.05$ & $5.06 \pm 0.07$ & $33.9 \pm 0.29$ \\
\hline & TTCA & 31 & $5.32 \pm 0.40^{\mathrm{ab}}$ & $9.41 \pm 0.21^{b}$ & $3.77 \pm 0.13$ & $4.89 \pm 0.19$ & $32.8 \pm 0.85$ \\
\hline & TCCC & 160 & $5.05 \pm 0.21^{b}$ & $9.59 \pm 0.11^{b}$ & $3.71 \pm 0.07$ & $5.12 \pm 0.10$ & $34.0 \pm 0.43$ \\
\hline & TCCA & 63 & $5.74 \pm 0.27^{a}$ & $10.01 \pm 0.14^{a}$ & $3.86 \pm 0.09$ & $5.28 \pm 0.13$ & $34.4 \pm 0.57$ \\
\hline
\end{tabular}

SNF content were affected positively by only the TC genotype (Table-6). However, such evidence has not been consistently found in sheep. Recently Giambra et al. [12] showed that CSN1S1 T allele had a positive significant effect on protein content, while there were no significant differences in fat content, when studying East Friesian and Lacaune sheep breeds.

On the other hand, Calvo et al. [23] claimed no association when they tested the influence of CSN1S1 gene on milk protein, lactose, and fat contents in Spanish Assaf sheep. The strength of the statistical procedures and the problem of false discovery rates and the genotype by environmental interaction, including different fixed or environmental included in the model, may explain the discrepancies about the effect of CSN1S1 on milk traits reported in our and other studies. Overall the observed effect of CSN1S1 on some milk composition traits, CSN1S1 gene variants should be included in selection criteria as a marker-assisted selection procedure for improving milk composition.

In the CSN2 gene, we found $\mathrm{C}$ allelic frequency higher than the A allele in Awassi sheep. However, animals with the AA genotype were not observed and the $\mathrm{CC}$ genotype prevailed over the CA genotype (Table-2). To the best of our knowledge, the present study associates, for the $1^{\text {st }}$ time, the CSN2 gene to milk production and composition. The AC genotype was associated with the highest milk production (Table-5), whereas the CSN2 genotypes had no distinct effect on milk composition traits (Table-6). Considering the effect of CSN2 polymorphism on the milk yield and quality, Corral et al. [14] found the GG genotype to cohort with high milk production. In contrast, the AA genotype was related to an increase in fat and protein percentages in Merino sheep breed.

On the other hand, Giambra et al. [12] found the genotypes of the CSN2 to have no significant effect on milk production and composition in East Friesian and Lacaune sheep. Genotypes combinations reflect the multiple genes effects in a certain quantitative variable [24] which is the interesting portion of our study. A significant interaction impact of the CSN $1 S 1 \times C S N 2$ genotypes on milk production (Table-5) was found. Milk production traits were the highest in Awassi ewes of TT $\times$ CA $(C S N 1 S 1 \times C S N 2)$ combined genotypes compared to the other genotype. However, our study indicated a significant interaction impact of CSN1S1 $1 \times C S N 2$ genotypes on milk composition traits. The statistical results show that ewes of $\mathrm{TT} \times \mathrm{CC}$ and $\mathrm{TC} \times \mathrm{CA}$ genotypes combination had the highest Fat $\%$, and $\mathrm{TC} \times \mathrm{CA}$ genotype combination had the highest SNF\% compared to other genotypes (Table-6).

\section{Conclusion}

The remarkable finding of this study was the significant genes combination impact on the Awassi sheep breed milk. The findings illustrated in this study figured out the single gene effect of CSNISI gene polymorphisms to be not associated with milk production traits; however, their interactions with CSN2 polymorphisms were observed to affect milk production and composition of Awassi sheep. This finding indicates the necessity of including those genes interaction effects as a marker to assist selection strategy for improving Awassi sheep milk productivity. On the other hand, CSN2 gene polymorphism was associated with high milk production while not associated with milk composition traits. The selection program that targeted the improvement of Awassi milk production in the commercial flocks should include those genes and their interaction as a remarkable way for rapid improvement of milk production and may reduce the generation intervals and genetics gained as a result from the selection. The commercial flocks herd book and DNA banks should be established to facilitate the selection procedure for gaining an accurate selection decision in Awassi sheep flocks.

\section{Authors' Contributions}

KIJ, AHA: Conceptualization and methodology, validation, formal analysis, investigation, resources, data collection, sequence analysis, drafted, and revised the manuscript. KIJ and AHA: DNA extraction, genotyping, and data analysis. All authors read and approved the final manuscript.

\section{Acknowledgments}

The study was funded by the Deanship of Research at Jordan University of Science and Technology (JUST) University (Grant \# 0301/2017). The authors are thankful to the Livestock and Range Land Research Directorate of NARC staff for helping in data collection from the commercial flocks. 


\section{Competing Interests} interests.

The authors declare that they have no competing

\section{Publisher's Note}

Veterinary World remains neutral with regard to jurisdictional claims in published institutional affiliation.

\section{References}

1. Gavran, M., Antunović, Z. and Gantner, V. (2021) Candidate genes associated with economically important traits of sheep-a review. Agric. Conspectus Sci., 86(3): 195-201.

2. Li, H., Wu, X.L., Tait, R.G. Jr., Bauck, S., Thomas, D.L., Murphy, T.W. and Rosa, G.J.M. (2020) Genome-wide association study of milk production traits in a crossbred dairy sheep population using three statistical models. Anim. Genet., 51(4): 624-628.

3. Xu, S.S. and Li, M.H. (2017) Recent advances in understanding genetic variants associated with economically important traits in sheep (Ovis aries) revealed by high-throughput screening technologies. Front. Agric. Sci. Eng., 4(3): 279-288.

4. Abousoliman, I., Reyer, H., Oster, M., Muráni, E., Mourad, M., Abdel-Salam Rashed, M., Mohamed, I. and Wimmers, K. (2020) Analysis of candidate genes for growth and milk performance traits in the Egyptian Barki sheep. Animals, 10(2): 197.

5. Balthazar, C.F., Pimentel, T.C., Ferrão, L.L., Almada, C.N., Santillo, A., Albenzio, M., Mollakhalili, N., Mortazavian, A.M., Nascimento, J.S., Silva, M.C., Freitas, M.Q., Sant'Ana, A.S., Granato, D. and Cruz, A.G. (2017) Sheep milk: Physicochemical characteristics and relevance for functional food development. Compr. Rev. Food Sci. Food Saf., 16(2): 247-262.

6. Ardicli, S., Soyudal, B., Samli, H., Dincel, D. and Balci, F. (2018) Effect of STAT1, OLR1, CSN1S1, CSN1S2, and DGAT1 genes on milk yield and composition traits of Holstein breed. R. Bras. Zootec., 47(1-9): e20170247.

7. Moioli, B., D'Andrea, M. and Pilla, F. (2007) Candidate genes affecting sheep and goat milk quality. Small Rumin. Res., 68(1-2): 179-192.

8. Gras, M.A., Rotar, C.M., Pelmus, R.S., Lazar, C., Ghita, E. and Grosu, H. (2017) Prolactin polymorphism effect over production traits types at Transylvanian Merino sheep. Sci. Papers Anim. Sci., 50(1): 56-60.

9. Chessa, S., Giambra, I., Brandt, H., Caroli, A., Gootwine, E. and Erhardt, G. (2017) Genetic diversity within economically important loci in European, Middle Eastern, and African sheep breeds: An insight into their development. Small Rumin. Res., 155: 72-80.

10. Chessa, S., Rignanese, D., Berbenni, M., Ceriotti, G., Martini, M., Pagnacco, G. and Caroli, A. (2010) New genetic polymorphisms within ovine $\beta$-and $\alpha \mathrm{S} 2$-caseins. Small Rumin. Res., 88(2-3): 84-88.

11. Ceriotti, G., Chessa, S., Bolla, P., Budelli, E., Bianchi, L., Duranti, E. and Caroli, A. (2004) Single nucleotide polymorphisms in the ovine casein genes detected by polymerase chain reaction-single strand conformation polymorphism. J. Dairy Sci., 87(8): 2606-2613.

12. Giambra, I.J., Brandt, H. and Erhardt, G. (2014) Milk protein variants are highly associated with milk performance traits in East Friesian Dairy and Lacaune sheep. Small Rumin. Res., 121(2-3): 382-394.

13. Provot, C., Persuy, M.A. and Mercier, J.C. (1995) Complete sequence of ovine $\beta$-casein-encoding gene and interspecies comparison. Gene, 154(2): 259-263.

14. Corral, J.M., Padilla, J.A. and Izquierdo, M. (2010) Associations between milk protein genetic polymorphisms and milk production traits in Merino sheep breed. Livest. Sci., 129(1-3): 73-79.

15. Kusza, S., Ilie, D.E., Sauer, M., Sauer, I.W. and Gavojdian, D. (2017) Preliminary report on $\beta$-casein gene Met183QVal183 polymorphism in Romanian indigenous Zackel sheep breeds. Acta Biochim. Polonica., 64(2): 339-341.

16. Ceriotti, G., Chiatti, F., Bolla, P., Martini, M. and Caroli, A. (2005) Genetic variability of the ovine $\alpha$ s1-casein. Ital. $J$. Anim. Sci., 4(2): 64-66.

17. Jawasreh, K., Amareen, A.A. and Aad, P. (2019) Effect and interaction of $\beta$ lactoglobulin, kappa casein, and prolactin genes on milk production and composition of Awassi Sheep. Animals, 9(6): 382.

18. Bastos, E., Cravador, A., Azevedo, J. and Guedes-Pinto, H. (2001) Single strand conformation polymorphism (SSCP) detection in six genes in Portuguese indigenous sheep breed "Churra da Terra Quente". Biotechnol. Agron. Soc. Environ., 5(1): 7-15.

19. Hall, T.A. (1999) BioEdit: A user-friendly biological sequence alignment editor and analysis program for windows 95/98/NT. Nucl. Acids Symp. Ser., 41(41): 95-98.

20. Yeh, F.C., Yang, R.C. and Boyle, T. (1999) POPGENE Version 1.32: Microsoft Window-Based Freeware for Population Genetics Analysis. University of Alberta, Edmonton, AB, Canada.

21. Othman, O.E., El-Fiky, S.A., Hassan, N.A., Mahfouz, E.R. and Balabel, E.A. (2013) Genetic polymorphism detection of two $\alpha$-Casein genes in three Egyptian sheep breeds. $J$. Gene. Eng. Biotechnol., 11(2): 129-134.

22. Giambra, I.J., Brandt, H. and Erhardt, G. (2012) Analyses of milk protein genes using protein and DNA based methods and their associations to milk performance traits in East Friesian Dairy sheep. In: The Proceedings $9^{\text {th }}$ International Symposium Milk Genomics and Human Health, Wageningen, Nederlands.

23. Calvo, J.H., Dervishi, E., Sarto, P., González-Calvo, L., Berzal-Herranz, B., Molino, F., Serrano, M. and Joy, M. (2013) Structural and functional characterisation of the $\alpha \mathrm{S} 1$-casein (CSN1S1) gene and association studies with milk traits in Assaf sheep breed. Livest. Sci., 157(1): 1-8.

24. Zheng, X., Ju, Z., Wang, J., Li, Q., Huang, J., Zhang, A., Zhong, J. and Wang, C. (2011) Single nucleotide polymorphisms, haplotypes and combined genotypes of LAP3 gene in bovine and their association with milk production traits. Mol. Biol. Rep., 38(6): 4053-4061. 